\title{
Effect of genetic type and casein haplotype on antioxidant activity of yogurts during storage
}

\author{
A. Perna, ${ }^{1}$ I. Intaglietta, A. Simonetti, and E. Gambacorta \\ School of Agricultural, Forestry, Food and Environmental Sciences, University of Basilicata, Potenza, Viale dell'Ateneo Lucano 10 - 85100 , Italy
}

\begin{abstract}
The aim of this work was to investigate the antioxidant activity of yogurt made from the milk of 2 breeds - Italian Brown and Italian Holstein - characterized by different casein haplotypes $\left(\alpha_{\mathrm{S}^{-}}, \beta-\right.$, and $\kappa$-caseins) during storage up to $15 \mathrm{~d}$. The casein haplotype was determined by isoelectric focusing; antioxidant activity of yogurt was measured using 2,2'-azino-bis-(3ethylbenzothiazoline-6-sulfonic acid). The statistical analysis showed a significant effect of the studied factors. Antioxidant activity increased during storage of both yogurt types, but yogurt produced with Italian Brown milk showed higher antioxidant activity than those produced with Italian Holstein milk. A high scavenging activity was present in yogurts with the allelic combination of $B B-A^{2} A^{2}-B B$. The results of this study suggest that the genetic type and the haplotype make a significant contribution in the production of yogurts with high nutraceutical value.
\end{abstract}

Key words: yogurt, genetic type, casein haplotype, antioxidant activity

\section{INTRODUCTION}

Interest in yogurt production is based on 3 fundamental aspects: (1) to create a particularly interesting nutraceutical product; (2) to transform milk without residue from processing; and (3) to reclaim and obtain a product without any risk of failure. Consumer interest in the consumption of yogurt has undergone a profound change, from being a product consumed by a few people to becoming a worldwide phenomenon, as consumers become more aware of the association between yogurt and welfare and disease prevention. Yogurt is now considered a functional food; it is a healthy food due to the high digestibility and bioavailability of its protein, energy, and calcium. In addition, the microbial fermentative activities (e.g., proteolysis) of yogurt lead to the modification of the allergenic properties of milk (Lourens-Hattingh and Viljoen, 2001) and to the release

Received June 21, 2012.

Accepted February 10, 2013.

${ }^{1}$ Corresponding author: anna.perna@unibas.it of several of bioactive peptides encrypted within the native sequence of the proteins (Gobbetti et al., 2004).

Previous research has shown that some qualities of yogurt, such as its antioxidative, antithrombotic, antimicrobial, immunomodulatory, ion binding, opioid antagonistic activities, or angiotensin-converting enzyme inhibitory qualities, have beneficial effects on bodily functions in humans (Pattorn et al., 2012). Many authors have shown that the antioxidant activity of whey and $\mathrm{CN}$ proteins in yogurt could be related to their high tendency to chelate metals (Tong et al., 2000; Rival et al., 2001) and to their ability to donate electrons and atoms (Colbert and Decker, 1991).

Milk proteins are prone to genetic variations; De Noni et al. (2009) demonstrated that genetic polymorphism may determine the type of bioactive peptides released from milk proteins. The relationships between genetic polymorphism and milk composition have been studied in depth by several authors (Ng-Kwai-Hang, 1998; Di Stasio and Mariani, 2000). In many studies, the effects of $\mathrm{CN}$ haplotypes on milk production were evaluated considering a single locus (Ng-Kwai-Hang et al., 1984; Aleandri et al., 1990; Bovenhuis et al., 1992). However, studies on the effects of individual loci are rather contradictory and, as shown in previous research, their influence on milk production could be due to the cumulative effect of different $\mathrm{CN}$ loci on chromosome 6 (Braunschweig et al., 2000). Grosclaude (1988) have suggested studying whole combinations of alleles rather than single alleles due to the tight genetic linkage among CN loci. Currently, it is believed that a better estimation of effects is obtained when considering the whole $\mathrm{CN}$ cluster instead of the single $\mathrm{CN}$ loci within a single breed (Gambacorta et al., 1994, 2005; Boettcher et al., 2004; Secchiari et al., 2009). The aim of this work was to evaluate the effect of genetic type and $\mathrm{CN}$ haplotype on the antioxidant capacity of yogurt during storage.

\section{MATERIALS AND METHODS}

\section{Samples}

This study was conducted on an intensive farm, consisting of more than 350 Italian Holstein and Italian 
Brown cattle, in the countryside of Potenza, southern Italy. Before starting the test, about 200 animals in lactation were identified by isoelectric focusing (IEF) to define their haplotypes. Haplotypes were formed by the combination of the individual allelic loci aggregated by the $\alpha_{S_{1}}, \beta-$, and $\kappa-C N$. After definition of individual phenotypes and separation by genetic type (GT), the cows were grouped by haplotype to obtain more consistent milk, which is needed to manufacture yogurt. Yogurt was obtained with a specific yogurt starter culture consisting of a mixture of 2 species of lactic acid bacteria (LAB)-Streptococcus thermophilus and Lactobacillus delbrueckii ssp. bulgaricus - and stored at $4^{\circ} \mathrm{C}$ for $3,6,9$, and $15 \mathrm{~d}$.

\section{Chemicals and Apparatus}

The chemical compound 2,2'-azino-bis-(3-ethylbenzothiazoline-6-sulfonic acid) (ABTS), potassium persulfate, sodium phosphate, sodium hydroxide, phosphoric acid, acetic acid, 2-mercaptoethanol, urea, $N, N, N^{\prime}, N^{\prime}$ tetramethylethylenediamine, ammonium persulfate, and sodium acetate were purchased from Sigma-Aldrich (Milan, Italy). Acrylamide, bis-acrylamide, ampholine buffer were purchased from GE Healthcare Amersham Bioscience (Buckinghamshire, UK). Coomassie Brilliant Blue G250 was purchased from Bio-Rad (Richmond, CA). The LAB, Lactobacillus delbrueckii ssp. bulgaricus and Streptococcus thermophilus, were purchased from Insao s.r.l. (Liscate, Milan, Italy). The spectrophotometer used was a UV-VIS Spectrophotometer 1204 (Shimadzu, Kyoto, Japan). The apparatus for IEF used was a Multiphor II Electrophoresis System (Pharmacia LKB, Sweden).

\section{Sample Preparation for IEF}

Individual milk samples, kept at $4^{\circ} \mathrm{C}$, were defatted by centrifugation $\left(3,000 \times g\right.$ for $30 \mathrm{~min}$ at $\left.4^{\circ} \mathrm{C}\right)$; the fat layer was solidified at $-20^{\circ} \mathrm{C}$ for $20 \mathrm{~min}$ and removed. Casein was prepared by isoelectric precipitation at $\mathrm{pH}$ 4.6 with $10 \%$ (vol/vol) acid acetic and $1 M$ sodium acetate at room temperature. After centrifugation at $3,000 \times g$ for $10 \mathrm{~min}$ at $4^{\circ} \mathrm{C}$, the $\mathrm{CN}$ pellet was washed twice with distilled water and stored at $-20^{\circ} \mathrm{C}$. The whole $\mathrm{CN}$ was dissolved in $9 \mathrm{M}$ urea and 1\% 2-mercaptoethanol for IEF analysis, according to Aschaffenburg and Drewry (1959).

\section{Genetic Variants of $\mathrm{CN}$ and Whey Proteins by IEF}

The genetic variants of the different $\mathrm{CN}$ by IEF were determined according to the method of Trieu-Cuot and Gripon (1981). The IEF analysis was performed on polyacrylamide gel ( $5 \%$ acrylamide and $0.15 \%$ bisacrylamide) with a thickness of $1 \mathrm{~mm}$ and $2 \%$ carrier ampholytes to create a gradient of $\mathrm{pH} 2.5$ to 10 . The gel was prefocused at a constant value of $0.35 \mathrm{~W} / \mathrm{mL}$ of gel and at the maximum limit of 1,200 V. The gel was stained in Coomassie Brilliant Blue G-250 according to Blakesley and Boezi (1977). Haplotype frequencies were determined by the number of each haplotype divided by the total number of haplotypes $\left[\%=\left(\mathrm{n}_{i, \text { haplotype }} / \mathrm{n}_{\text {tot }}\right.\right.$, haplotype $) \times 100]$. Haplotypes are presented as $\alpha_{\mathrm{S}^{-}}, \beta-$, and $\mathrm{k}-\mathrm{CN}$.

\section{Yogurt Manufacture}

After heat treatment at $95^{\circ} \mathrm{C}$ for 15 min followed by cooling to $45^{\circ} \mathrm{C}$, whole milk samples were inoculated at the same time with $1 \%$ (vol/vol) Streptococcus thermophilus and Lactobacillus delbrueckii ssp. bulgaricus. Fermentation was carried out at $45^{\circ} \mathrm{C}$; each fermentation process was monitored systematically by recording the $\mathrm{pH}$ values at intervals of $30 \mathrm{~min}$ until the $\mathrm{pH}$ value reached $4.6 \pm 0.1$. Yogurts were immediately cooled after fermentation at $4^{\circ} \mathrm{C}$ and stored for $3,6,9$, and $15 \mathrm{~d}$.

\section{Preparation of Water-Soluble Extracts of Milk and Yogurt}

Milk and yogurt samples were centrifuged at 5,000 $\times g$ at $4^{\circ} \mathrm{C}$ for $20 \mathrm{~min}$. The supernatant was separately filtered through a membrane filter $(0.45 \mathrm{~nm})$ and was used to measure the antioxidant activity.

\section{Antioxidant Activity of ABTS Radical Scavenging Assay}

A modification of the original method of Re et al. (1999) was applied to assess the scavenging capacity of yogurt samples in a reaction with the ABTS radical cation $\left(\mathrm{ABTS}^{++}\right)$, generated by oxidation of ABTS diammonium salt stock solution with potassium persulfate $\left(\mathrm{K}_{2} \mathrm{~S}_{2} \mathrm{O}_{8}\right)$. Stock solutions of ABTS $(7 \mathrm{mM})$ and potassium persulfate $(140 \mathrm{mM})$ were prepared in water, and $\mathrm{ABTS}^{++}$radical solution was produced by reacting $10 \mathrm{~mL}$ of the ABTS stock solution with 175 $\mu \mathrm{L}$ of potassium persulfate solution. The mixture was left in the dark at room temperature for 12 to $16 \mathrm{~h}$ before use. For the evaluation of antioxidant capacity, the $\mathrm{ABTS}^{++}$solution was diluted with ethanol $(96 \%)$ to obtain the absorbance of $0.700 \pm 0.020$ at $734 \mathrm{~nm}$. Two milliliters of $\mathrm{ABTS}^{++}$solution was mixed with $100 \mu \mathrm{L}$ of the water-soluble extracts of samples in a cuvette and the decrease in the absorbance was measured after 30 min. The reagent blank was prepared by adding $100 \mu \mathrm{L}$ of ethanol instead of the sample. Antioxidant activity 
was expressed as a percentage inhibition $(I)$ of $\mathrm{ABTS}^{++}$ radical and calculated by the equation

$$
I(\%)=\left(\frac{A_{734}^{\text {Control }}-A_{734}^{\text {Extract }}}{A_{734}^{\text {Control }}}\right) \times 100 .
$$

\section{Statistical Analysis}

Data were analyzed according to the following linear model (SAS Institute, 1996):

$$
\mathrm{y}_{i j k}=\mu+\alpha_{i}+\beta_{j}+(\alpha \beta)_{i j}+\varepsilon_{i j k},
$$

where $\mathrm{y}_{i j k}$ is the observation; $\mu$ is the overall mean; $\alpha_{i}$ is the fixed effect of the $i$ th GT $(i=1,2) ; \beta_{j}$ is the fixed effect of the $j$ th haplotype $(j=1,2,3,4,5,6,7)$; $(\alpha \beta)_{i j}$ is the interaction of GT $\times$ haplotype; and $\varepsilon_{i j k}$ is the random error. Before setting the values, expressed as a percentage, they were subjected to angular transformation. Student's $t$-test was used to for all variable comparisons and correlation between parameters was determined by Pearson correlation analysis.

\section{RESULTS AND DISCUSSION}

\section{Haplotype Frequencies}

Seven different CN haplotypes were identified by isoelectric focusing. The different allelic combinations of loci $\alpha_{\mathrm{S1}^{-}}, \beta$-, and $\kappa-\mathrm{CN}$ and their frequencies are reported in Table 1. Alleles $B B-A^{2} A^{1}-A A$ and $B B-A^{2} A^{2}$ $B B(20.83 \%)$ and $B B-A^{2} B-A B(16.67 \%)$ were frequent, whereas $B B-A^{2} A^{2}-A A, B B-A^{2} A^{2}-A B$, and $B B-A^{2} A^{2}-B B$ showed the lowest frequency (8.34\%). All haplotypes were present in the Italian Brown population, whereas haplotypes $C C-A^{2} A^{2}-B B$ and $B B-A^{2} B-A B$ were absent in the Italian Holstein population. The selection boost carried out only for specific aspects related to some phenotypic characteristics of milk (e.g., fat and protein yield) led to a reduction of the variability of allelic combinations.

\section{Antioxidant Activity}

The decolorization of the ABTS radical cation $\left(\mathrm{ABTS}^{\bullet+}\right)$ was used to assess the antioxidant activity of yogurt samples. The ABTS assay is one of the most widely used methods for the screening of antioxidant activity as it measures the scavenging activity of several natural products and is applicable to both hydrophilic and lipophilic antioxidant systems (Re et al., 1999). The ABTS values were expressed in terms of inhibition percentage $(I, \%)$, which is reported in Table 2. The antioxidant activity was measured on both milks, aggregates for single haplotypes, and on obtained yogurts. The results of the study on milk ABTS showed very low variability and statistical significance, so the results were omitted. This could be related to the presence of large peptides and proteins not hydrolyzed, which have low antioxidant activity (Hernández-Ledesma et al., 2005a).

The role of bacteria fermentation on the production of different bioactive peptides and the relationship between antioxidant activity and concentration of low molecular weight peptides has been reported in many studies (Kudoh et al., 2001; Virtanen et al., 2007; Gomez-Ruiz et al., 2008). The antioxidant capacity is also conditioned by the heat treatment undergone by the milk for the manufacture of the yogurt $\left(95^{\circ} \mathrm{C}\right.$ for $15 \mathrm{~min}$ ) because the denaturation of proteins exposed initially buried reactive sites (Galleher et al., 2005).

The antioxidant activity of the yogurt was evaluated during storage at $4^{\circ} \mathrm{C}$ and up to $15 \mathrm{~d}$ (Table 2). Although the shelf life of yogurt is at least $30 \mathrm{~d}$, in a previous study (E. Gambacorta, I. Intaglietta, A. Simonetti and A. Perna, unpublished data) we observed that the ABTS values increased up to $15 \mathrm{~d}$, and storage to $30 \mathrm{~d}$ resulted in very small variation with no detectable statistically significant differences. This finding was similar to that of Shori and Baba (2011), who reported a similar trend in the antioxidant activity of yogurt during refrigerated storage up to $14 \mathrm{~d}$. All yogurt samples showed antioxidant activity at formation $(1 \mathrm{~d})$. At $1 \mathrm{~d}$, the average ABTS value was $52.38 \%$, with a variation of 45.98 to $57.98 \%$; the antioxidant activity gradually increased during refrigerated storage (1-15 d; Table 2). The ABTS radical scavenging activity reached its highest value at $15 \mathrm{~d}(I=70.97 \%)$, with an increase of about $37 \%$ over the initial value $(I$ $=52.38 \%)$. Our results are in agreement with those reported by Gupta et al. (2009), who observed an increase in antioxidant activity as ripening proceeded in Cheddar cheese samples, reaching a maximum value during the fourth month. The relationship between radical scavengers' activity and proteolysis was previ-

Table 1. Frequencies of the $\alpha_{\mathrm{S1}^{-}}, \beta-$, and $\kappa$-CN haplotypes in Italian Brown and Italian Holstein cows

\begin{tabular}{lc}
\hline $\begin{array}{l}\text { Haplotype } \\
\left(\alpha_{\mathrm{S} 1}-\mathrm{CN}, \beta-\mathrm{CN}, \kappa-\mathrm{CN}\right)\end{array}$ & $\begin{array}{c}\text { Frequency } \\
(\%)\end{array}$ \\
\hline$B B, A^{2} A^{1}, A A$ & 20.83 \\
$B B, A^{2} A^{2}, B B$ & 20.83 \\
$B B, A^{2} B, A B$ & 16.67 \\
$B B, A^{2} A^{1}, A B$ & 12.50 \\
$C C, A^{2} A^{2}, B B$ & 12.50 \\
$B B, A^{2} A^{2}, A B$ & 8.33 \\
$B B, A^{2} A^{2}, A A$ & 8.33 \\
\hline
\end{tabular}


Table 2. Radical-scavenging activity of yogurts during storage at $4^{\circ} \mathrm{C}$ for up to $15 \mathrm{~d}^{1}$

\begin{tabular}{|c|c|c|c|c|c|c|c|c|c|c|}
\hline Item & \multicolumn{10}{|c|}{ Days } \\
\hline \multicolumn{11}{|l|}{ Genetic type } \\
\hline Italian Brown & $53.09^{\mathrm{a}}$ & 4.78 & $58.44^{\mathrm{a}}$ & 3.63 & $61.16^{\mathrm{a}}$ & 1.88 & $69.35^{\mathrm{a}}$ & 4.90 & $70.50^{\mathrm{a}}$ & 3.47 \\
\hline Italian Holstein & $51.67^{\mathrm{b}}$ & 3.88 & $56.16^{\mathrm{b}}$ & 2.64 & $61.49^{\mathrm{b}}$ & 1.77 & $64.84^{\mathrm{b}}$ & 3.53 & $71.43^{\mathrm{b}}$ & 3.49 \\
\hline$B B, A^{2} A^{1}, A B$ & $51.31^{\mathrm{b}}$ & 1.55 & $57.74^{\mathrm{b}}$ & 1.88 & $60.27^{\mathrm{b}}$ & 1.10 & $69.01^{\mathrm{b}}$ & 3.70 & $70.36^{\mathrm{b}}$ & 0.79 \\
\hline$B B, A^{2} A^{2}, A A$ & $57.98^{\mathrm{c}}$ & 2.03 & $61.45^{\mathrm{c}}$ & 1.94 & $63.14^{\mathrm{ce}}$ & 0.69 & $74.87^{\mathrm{c}}$ & 4.06 & $71.15^{\mathrm{c}}$ & 0.65 \\
\hline$B B, A^{2} A^{2}, A B$ & $45.98^{\mathrm{d}}$ & 0.96 & $51.30^{\mathrm{d}}$ & 0.96 & $59.51^{\mathrm{a}}$ & 1.20 & $64.68^{\mathrm{a}}$ & 1.43 & $70.70^{\mathrm{bc}}$ & 1.00 \\
\hline$B B, A^{2} A^{2}, B B$ & $48.65^{\mathrm{e}}$ & 1.11 & $57.00^{\mathrm{a}}$ & 1.97 & $62.56^{\mathrm{c}}$ & 0.93 & $62.70^{\mathrm{d}}$ & 3.19 & $73.18^{\mathrm{d}}$ & 1.67 \\
\hline$B B, A^{2} B, A B$ & $50.74^{\mathrm{b}}$ & 1.10 & $58.26^{\text {be }}$ & 1.90 & $61.32^{\mathrm{d}}$ & 1.70 & $66.33^{\mathrm{e}}$ & 1.94 & $71.28^{\mathrm{c}}$ & 2.08 \\
\hline$C C, A^{2} A^{2}, B B$ & $57.46^{\mathrm{c}}$ & 1.58 & $58.40^{\mathrm{e}}$ & 1.96 & $62.90^{\mathrm{e}}$ & 0.64 & $67.23^{\mathrm{f}}$ & 3.51 & $75.83^{\mathrm{e}}$ & 1.44 \\
\hline Overall & 52.38 & 4.40 & 57.30 & 3.36 & 61.32 & 1.82 & 67.09 & 4.82 & 70.97 & 3.50 \\
\hline
\end{tabular}

${ }^{\mathrm{a}-\mathrm{f}}$ Means within a column with different superscripts differ $(P<0.01)$.

${ }^{1}$ Measured using 2,2'-azino-bis-(3-ethylbenzothiazoline-6-sulfonic acid) (ABTS) assay and expressed as percentage inhibition $(I)$ of the ABTS ${ }^{+}$ radical.

ously reported in several studies (Kudoh et al., 2001; Ryhanen et al., 2001; Hernández-Ledesma et al., 2005b; Gupta et al., 2009). Antioxidant activity attributed to yogurt is also influenced by the fermentation and postacidification during storage that determine production of organic acids (Correia et al., 2004) characterized by biological activity. Statistical analysis by 2 -way ANOVA showed a statistically significant effect of the GT and haplotype $(P<0.001)$. Differences observed by $t$-test for the mean ABTS values are presented in Table 2. Comparing different GT, the differences between the ABTS average values were statistically significant $(P<$ $0.05)$ in all studied levels. Italian Brown yogurts showed the highest antioxidant activity compared with Italian Holstein yogurts $(P<0.05)$. Chiang and Chang $(2005)$ highlighted the positive correlation between protein content and antioxidant activity. In fact, Italian Brown presents higher protein content than the Italian Holstein (3.79 vs. $3.24 \%$, respectively) and CN nitrogen (2.75 vs. $2.28 \%$, respectively; results not shown) in particular, as reported by De Marchi et al. (2007). Previous research reported that $\mathrm{CN}$ represent the primary substrate for proteolysis operated by bacterial starter and a reserve for a wide variety of bioactive peptides (Meisel, 1998).

The percentage change of antioxidant activity encountered at different stages and compared with the initial value gives an indication of the progress of the process at different intervals: 1 to 3,1 to 6,1 to 9 , and 1 to $15 \mathrm{~d}$ (Figure 1 and Figure 2). In general, the antioxidant capacity increased, Italian Holstein yogurt showed a trend of steady increase and the Italian Brown yogurt showed a much more marked variation in the third interval (Figure 1). These findings suggest that antioxidant activity, despite being dependent on the degree of proteolysis, is strongly influenced by strain-specific characteristics of LAB (Kudoh et al., 2001; Ryhanen et al., 2001; Hernández-Ledesma et al., 2005b; Virtanen et al., 2007; Gupta et al., 2009). Hajirostamloo (2010) reported that the concentration of angiotensin-converting-enzyme (ACE)-inhibitory peptides depends on a balance between their formation and further breakdown into inactive peptides and amino acids that, in turn, depends on storage time and conditions. Conversely, the variation of antioxidant activity is linked to the possible aggregation of peptide processes that occur during the enzymatic hydrolysis of whey protein and $\mathrm{CN}$, with formation of macro-aggregates that reduce the antioxidant capacity (Adt et al., 2011).

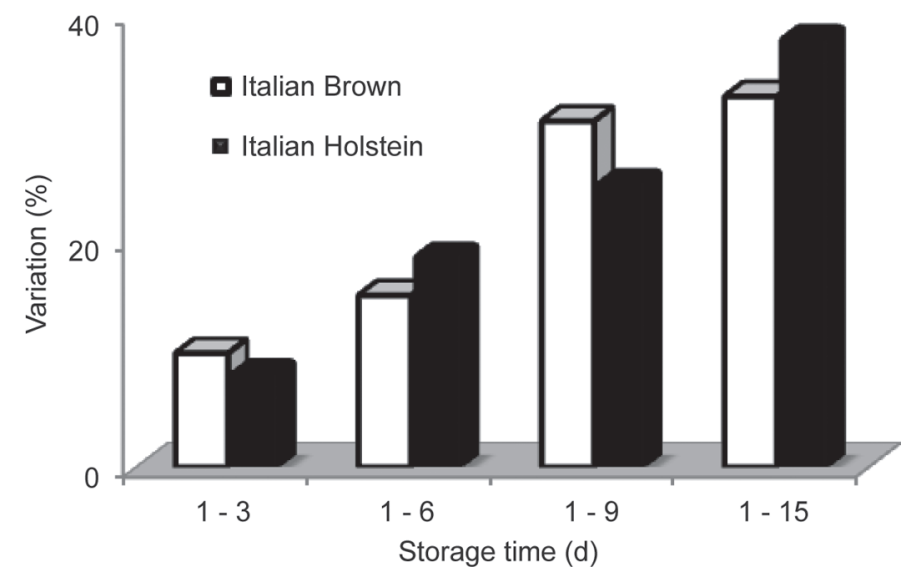

Figure 1. Percentage variation of antioxidant activity in Italian Brown and Italian Holstein yogurt during storage for $15 \mathrm{~d}$, measured using 2,2'-azino-bis-(3-ethylbenzothiazoline-6-sulfonic acid) (ABTS) assay and expressed as percentage inhibition $(I)$ of the $\mathrm{ABTS}^{\bullet+}$ radical. 

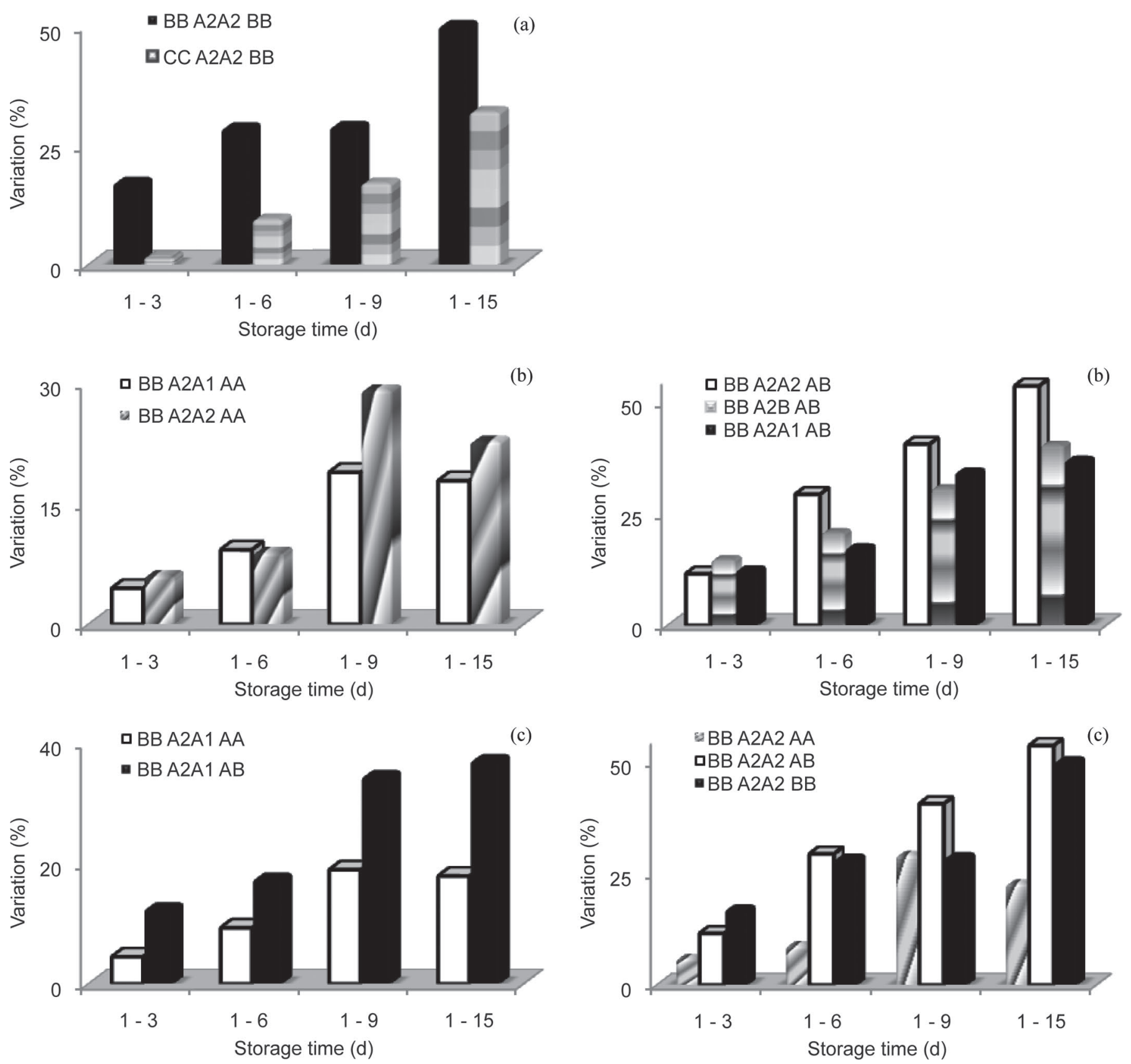

Figure 2. Percentage variation of antioxidant activity, measured using 2,2'-azino-bis-(3-ethylbenzothiazoline-6-sulfonic acid) (ABTS) assay and expressed as percentage inhibition $(I)$ of the $\mathrm{ABTS}^{\bullet+}$ radical in yogurt with different $\mathrm{CN}$ haplotypes during 15 -d storage: (a) same phenotypes for $\beta$ - and $\kappa-\mathrm{CN}$; (b) same phenotypes for $\alpha_{\mathrm{S1}}$ and $\kappa-\mathrm{CN}$; (c) same phenotypes for $\alpha_{\mathrm{S1}^{-}}$and $\beta$-CN. Haplotypes are expressed as the alleles for $\alpha_{\mathrm{S} 1}-\mathrm{CN}(B B$ or $C C), \beta-\mathrm{CN}\left(A^{2} A^{2}, A^{2} A^{1}, A^{2} B\right)$, and $\kappa-\mathrm{CN}(A A, B B$, and $A B)$.

Antioxidant activity is influenced by the CN haplotype. The degree of $\mathrm{CN}$ heterogeneity may influence the release of peptides formed by proteolysis (Minervini et al., 2003) because of the primary structure, original conformation, and proportion of CN (Ng-Kwai Hang and Grosclaude, 1992). This is due to the presence in the sequence of a specific protein known as the stra- tegic zone that has biological activities (Fiat and Jollés, 1989). The ABTS values of samples with different haplotypes are shown in Table 2. Antioxidant activity showed different values as a function of the haplotype linked to the release of bioactive peptides. At $1 \mathrm{~d}$, the increasing sequence of radical scavenging of the yogurt with different haplotypes was $C C-A^{2} A^{2}-B B>B B-A^{2} A^{2}$ - 
$A A>B B-A^{2} A^{1}-A A>B B-A^{2} A^{1}-A B>B B-A^{2} B-A B>$ $B B-A^{2} A^{2}-B B>B B-A^{2} A^{2}-A B$. After 15 d, yogurt with the haplotype $C C-A^{2} A^{2}-B B$ showed the highest radical scavenging activity $(75.83 \%)$, whereas yogurt with the haplotype $B B-A^{2} A^{1}-A A$ showed the lowest value (64.26\%; Table 2). The different antioxidant activity observed among yogurts with different haplotypes could be due to the specific amino acid sequence of the milk protein variants. Hernández-Ledesma et al. (2004) showed that the formation of an angiotensinI-converting enzyme is peptide specific to the bovine $A^{1}$ variant and is not present in other $\beta$-CN alleles. Jinsmaa and Yoshikawa (1999) have reported that the release of $\beta$-casomorphin 7 does not occur in presence of Pro in position 67 of the $A^{2}$ variant of $\beta$-CN. Hernández-Ledesma et al. (2005b) have demonstrated that peptides released from the $A$ variant of $\beta-\mathrm{LG}$ are small $(3 \mathrm{kDa})$ and are mainly responsible for antioxidant activity compared with the $A B$ variant of $\beta-\mathrm{LG}$. The haplotype gives an indication of phenotypic expression coded by well-defined allelic combinations. The effect of an allele combination cannot be regarded as a mere summation of the effects of individual alleles, but as an expression of the interaction between them. This means that a single allele causes different results depending on the combination that contributes to the formation of the haplotype.

Genetic changes may alter the properties of individual proteins, affect the state of aggregation of the micellar system, and interfere with the action of proteolytic enzymes. Interactions that are established at the level of closely associated loci influence the effect of single alleles with regard to antioxidant activity. The analysis of results showed that the effect of the allelic combination $B B$ rather than $C C$ of $\alpha_{S_{1}-} \mathrm{CN}$, in the context of the haplotype $A^{2} A^{2} \beta-\mathrm{CN}$ and $B B \kappa-\mathrm{CN}$, always presents an expression of the highest antioxidant activity in all intervals (Figure 2). The allelic combination $A^{2} A^{2} \beta-\mathrm{CN}$, in the context of the haplotype $B B \alpha_{\mathrm{S} 1}$ and $A B \kappa-\mathrm{CN}$, resulted in an increasingly high antioxidant activity, except in the first interval (1-3 d), whereas the combination $A^{2} A^{1} \beta$-CN resulted in lower antioxidant activity. The combination $A^{2} B \beta-\mathrm{CN}$ positioned itself to a radical scavenger intermediate level, except during the third interval (1-9 d; Figure 2). The location of the combination $A^{2} A^{2} \beta-\mathrm{CN}$, compared with $A^{2} A^{1}$, was also preserved in the context of the haplotype $B B-A A$ $\alpha_{S 1}-\kappa-C N$. The allelic combination $A A \kappa-C N$, in the context of $B B \alpha_{\mathrm{S1}^{-}}$and $A^{2} A^{1} \beta-\mathrm{CN}$, was expressed with a lower antioxidant activity in all intervals than $A B$ $\kappa$-CN. No change was observed when 2 combinations of $\kappa-\mathrm{CN}$ were inserted in the context of $B B \alpha_{\mathrm{S1}^{-}}$and $A^{2} A^{2} \beta$-CN. The effect of the allelic combination $B B$ $\kappa-\mathrm{CN}$ in the context of $B B \alpha_{\mathrm{S} 1^{-}}$and $A^{2} A^{2} \beta-\mathrm{CN}$ was highest in the first interval (1-3 d), whereas the other 2 allelic combination expressions remained intermediate in the subsequent intervals (Figure 2). The analysis of the results showed that the combination of $B B \kappa-\mathrm{CN}$ was expressed at higher values than those of $A A \kappa-\mathrm{CN}$. $\mathrm{Ng}$-Kwai-Hang et al. (1984) reported that the $B B \kappa-\mathrm{CN}$ had a significant effect on milk production, protein, fat content, and technological properties. Although the best result was conditioned by heterozygous $A B \kappa-\mathrm{CN}$, this could be a heterotic effect.

\section{CONCLUSIONS}

The formation of biologically active peptides is strongly influenced by $\mathrm{CN}$ polymorphism, which was shown by the significant difference between different haplotypes in yogurt. Genetic type influenced the concentration of milk proteins, in particular on $\mathrm{CN}$ that are the main substrate of fermentation in starter bacteria for yogurt production, which resulted in the formation of biopeptides. Few studies have been done on the effect of casein haplotype on antioxidant activity of yogurts; therefore, the knowledge on this subject is not complete. More studies are therefore needed to confirm these findings and to understand the effects of milk protein polymorphism on the antioxidant activity of yogurt and evaluate the possible nutritional implications for human health.

\section{REFERENCES}

Adt, I., C. Dupas, R. Boutrou, N. Oulahal, C. Noel, and D. Mollé 2011. Identification of caseinophosphopeptides generated through in vitro gastro-intestinal digestion of Beaufort cheese. Int. Dairy J. 21:129-134.

Aleandri, R., L. G. Buttazzoni, J. C. Schneider, A. Caroli, and R. Davoli. 1990. The effects of milk protein polymorphisms on milk components and cheese-producing ability. J. Dairy Sci. 73:241255.

Aschaffenburg, R., and J. Drewry. 1959. New procedure for the routine determination of the various non-casein proteins of milk. 15th Int. Dairy Congr. London, UK. 3:1631-1637. Richard Clay and Co. Bungay, Suffolk, UK.

Blakesley, R. W., and J. A. Boezi. 1977. A new staining technique for proteins in polyacrylamide gels using Coomassie Brilliant Blue G250. Anal. Biochem. 82:580-582.

Boettcher, P. J., A. Caroli, A. Stella, S. Chessa, E. Budelli, F. Canavesi, S. Ghiroldi, and G. Pagnacco. 2004. Effects of casein haplotype on milk production traits in Italian Holstein and Brown Swiss Cattle. J. Dairy Sci. 87:4311-4317.

Bovenhuis, H., J. A. M. V. Arendonk, and S. Korver. 1992. Association between milk protein polymorphism and milk production traits. J. Dairy Sci. 74:2549-2559.

Braunschweig, M., C. Hagger, G. Stranzinger, and Z. Puhan. 2000. Association between casein haplotype and milk production traits of Swiss cattle. J. Dairy Sci. 83:1387-1395.

Chiang, S. H., and C. Y. Chang. 2005. Antioxidant properties of caseins and whey proteins from colostrums. J. Food and Drug Anal. 13:57-63.

Colbert, L. B., and E. A. Decker. 1991. Antioxidant activity of an ultrafiltration permeate from acid whey. J. Food Sci. 56:1248-1250. 
Correia, I., A. Nunes, I. F. Duarte, A. Barros, and I. Elgadillo. 2004. Sorghum fermentation followed by spectroscopic techniques. Food Chem. 90:853-859.

De Marchi, M., R. Dal Zotto, M. Cassandro, and G. Bittante. 2007. Milk coagulation ability of five dairy cattle breeds. J. Dairy Sci. 90:3986-3992.

De Noni, I., R. J. FitzGerald, H. J. T. Korhonen, Y. Le Roux, C. T. Livesey, I. Thorsdottir, D. Tomé, and R. Witkamp. 2009. Review of the potential health impact of $\beta$-casomorphins and related peptides. EFSA Sci. Rep. 231:1-107.

Di Stasio, L., and P. Mariani. 2000. The role of protein polymorphism in the genetic improvement of milk production. Zootec. Nutr. Anim. 3:69-90.

Fiat, A. M., and P. Jollès. 1989. Caseins of various origins and biologically active casein peptides and oligosaccharides: structural and physiological aspects. Mol. Cell. Biochem. 87:5-30.

Galleher, J. J., R. Hollender, D. G. Peterson, R. F. Roberts, and J. N. Coupland. 2005. Effect of composition and antioxidants on the oxidative stability of fluid milk supplemented with an algae oil emulsion. Int. Dairy J. 15:333-341.

Gambacorta, E., C. Cosentino, M. Gambacorta, D. Marsico, and A. Perna. 2005. Podolian breed cows: Casein genotype and cheesemaking attitude in pasta filata and in hard pressed curd cheese. Pages 153-162 in Proc. 40th Simp. Intern. Zootec. From Genome to Proteome in Animal Science. Istituto Sperimentale Italiano "Lazzaro Spallanzani," Lodi, Italy.

Gambacorta, E., A. Perna, and E. Cosentino. 1994. Attitudine alla caseificazione del latte di bovine Jersey in funzione del genotipo ai loci $\alpha_{\mathrm{s} 1}, \beta$, k-caseina. Pages 953-956 in Proc. 18th World Buiatrics Congress. Bologna, Italy. Editografica, Bologna, Italy.

Gobbetti, M., F. Minervini, and C. G. Rizzello. 2004. Angiotensin Iconverting enzyme-inhibitory and antimicrobial bioactive peptide. Int. J. Dairy Technol. 57:172-188.

Gomez-Ruiz, J., I. Lopez-Exposito, A. Pihlanto, M. Ramos, and I. Recio. 2008. Antioxidant activity of ovine casein hydrolysates: Identification of active peptides by HPLC-MS/MS. Eur. Food Res. Technol. 227:1061-1067.

Grosclaude, F. 1988. Le polymorphisme génétique des principales lactoprotéines bovines. INRA Prod. Anim. 1:5-17.

Gupta, A., B. Mann, R. Kumar, and R. Sangwan. 2009. Antioxidant activity of Cheddar cheeses at different stages of ripening. Int. J. Dairy Technol. 62:339-347.

Hajirostamloo, B. 2010. Bioactive component in milk and dairy product. World Acad. Sci. Eng. Technol. 72:162-166.

Hernández-Ledesma, B., L. Amigo, M. Ramos, and I. Recio. 2004. Release of angiotensin converting enzyme-inhibitory peptides by simulated gastrointestinal digestion of infant formulas. Int. Dairy J. 14:889-898

Hernández-Ledesma, B., A. Dávalos, B. Bartolomé, and L. Amigo. 2005a. Preparation of antioxidant enzymatic hydrolysates from $\alpha$-lactoalbumin and $\beta$-lactoglobulin. Identification of active peptides by HPLC-MS/MS. J. Agric. Food Chem. 53:588-593.

Hernández-Ledesma, B., B. Miralles, L. Amigo, M. Ramos, and I. Recio. 2005b. Identification of antioxidant and ACE-inhibitory peptides in fermented milk. J. Sci. Food Agric. 85:1041-1048.

Jinsmaa, Y., and M. Yoshikawa. 1999. Enzymatic release of neocasomorphin and $\beta$-casomorphin from bovine $\beta$-casein. Peptides 20:957-962.
Kudoh, Y., S. Matsuda, K. Igoshi, and T. Oki. 2001. Antioxidative peptide from milk fermented with Lactobacillus delbrueckii subsp. bulgaricus IFO 13953. J. Jpn. Soc. Food Sci. Technol. 48:44-50.

Lourens-Hattingh, A., and B. C. Viljoen. 2001. Yogurt as probiotic carrier food. Int. Dairy J. 11:1-17.

Meisel, H. 1998. Overview on milk protein-derived peptides. Int. Dairy J. 8:363-373.

Minervini, F., F. Algaron, G. C. Rizello, P. F. Fox, V. Monnet, and M. Gobbetti. 2003. Angiotensin I-converting-enzyme-inhibitory and antibacterial peptides from Lactobacillus helveticus PR4 proteinase-hydrolyzed caseins of milk from six species. Appl. Environ. Microbiol. 69:5297-5305.

Ng-Kwai-Hang, K. F. 1998. Genetic polymorphism of milk proteins: Relationships with production traits, milk composition and technological properties. Can. J. Anim. Sci. 78:131-147.

Ng-Kwai-Hang, K. F., and F. Grosclaude. 1992. Genetic polymorphism of milk proteins. Pages 405-455 in Advanced Dairy Chemistry 1. Elsevier, Amsterdam, the Netherlands.

Ng-Kwai-Hang, K. F., J. F. Hayes, J. E. Moxley, and H. G. Monardes. 1984. Association of genetic variants of casein and milk serum proteins with milk, fat, and protein production by dairy cattle. J. Dairy Sci. 67:835-840.

Pattorn, S., Y. Horimoto, P. Hongsprabhas, and R. Y. Yada. 2012 Influence of aggregation on the antioxidative capacity of milk peptides. Int. Dairy J. 25:3-9.

Re, R., N. Pellegrini, A. Proteggente, A. Pannola, M. Yang, and C. Rice-Evans. 1999. Antioxidant activity applying en improved ABTS radical cation decolorization assay. Free Radic. Biol. Med. 26:1231-1237.

Rival, S. G., C. G. Boeriu, and H. J. Wichers. 2001. Caseins and casein hydrolysates. Antioxidative properties and relevance to lipoxygenase inhibition. J. Agric. Food Chem. 49:295-302.

Ryhanen, E. L., L. A. Pihlanto, and E. Pahkala. 2001. A new type of ripened low-fat cheese with bioactive properties. Int. Dairy J. 11:441-447.

SAS Institute. 1996. SAS User's Guide: Statistics. Version 7. SAS Inst. Inc., Cary, NC.

Secchiari, P. L., P. Carnier, A. Priolo, and M. Mele. 2009. Genetic and physiology basis of the quality of livestock products. Italian J. Agron. 1:81-102.

Shori, A. B., and A. S. Baba. 2011. Antioxidant activity and inhibition of key enzymes linked to type-2 diabetes and hypertension by Azadirachta indica-yogurt. J. Saudi Chem. Soc. 10.1016/j. jscs.2011.04.006. (In press.)

Tong, L. M. S. Sasaki, D. J. McClements, and E. A. Decker. 2000. Mechanism of the antioxidant activity of high molecular weight fraction of whey. J. Agric. Food Chem. 48:1473-1478.

Trieu-Cuot, P., and J. C. Gripon. 1981. Electrofocusing and two dimensional electrophoresis of bovine caseins. J. Dairy Res. 48:303310

Virtanen, T., A. Pihlanto, S. Akkanen, and H. Korhonen. 2007. Development of antioxidant activity in milk whey during fermentation with lactic acid bacteria. J. Appl. Microbiol. 102:106-115. 